\title{
UNDERSTANDING MULTIPLE DIMENSIONS OF COMPENSATION SATISFACTION
}

\author{
Margaret L. Williams \\ Michael A. McDaniel \\ Virginia Commonwealth University \\ Lucy R. Ford \\ Rutgers University
}

\begin{abstract}
We conducted meta-analyses of multiple dimensions of compensation satisfaction. An examination of 213 samples from 182 studies yielded several interesting findings of importance to practice and future research. We examined the relationships among four dimensions of compensation satisfaction (pay level, pay raises, benefit level, pay structure and administration satisfaction), and found that the three dimensions related to direct pay are highly related to one another. The relationships between benefits and the three direct pay dimensions were modest. We also analyzed antecedents, correlates, and consequences of the four compensation satisfaction dimensions. The antecedents of pay raise satisfaction have received the most attention, and our results indicate that both perceptual (e.g., perceptions of the basis for a pay raise) and objective (i.e., the amount of the pay raise) antecedents play roles in determining pay raise satisfaction. Previous research on the relationship between employee costs for benefits and benefit satisfaction have been inconclusive. The meta-analysis yields a modest, negative relationship between employee costs and benefit satisfaction. Additional results provide the foundation for our discussion of the current state of research in these areas, recommendations for practice, and suggestions for future research.
\end{abstract}

KEY WORDS: compensation satisfaction; benefits; meta-analysis.

In the early $1960 \mathrm{~s}$, researchers first exhibited interest in assessing and studying employees' satisfaction with compensation. For example, both of the comprehensive measures of job satisfaction published in the

Address correspondence to Margaret L. Williams, School of Business, Virginia Commonwealth University, 1015 Floyd Avenue, P.O. Box 844000, Richmond, VA 23284-4000, USA. E-mail: mlwillia@vcu.edu 
1960s, the Job Descriptive Index (JDI) and the Minnesota Satisfaction Questionnaire (MSQ), included a pay or compensation satisfaction dimension (Smith, Kendall, \& Hulin, 1969; Weiss, Dawis, England, \& Lofquist, 1967). Subsequent to the development of the JDI and the MSQ, and buoyed by theoretical models of the causes of pay satisfaction (Lawler, 1971), research on satisfaction with pay began to appear (e.g., Dyer \& Theriault, 1976; Shapiro, 1976). Most of the early work concentrated on understanding pay satisfaction as a general construct (i.e., "overall" or "general" pay satisfaction); however, some studies appeared that assessed satisfaction with specific dimensions of compensation satisfaction such as satisfaction with the way in which pay systems were administered (e.g., Weiner, 1980). Over the past 35 years a body of research on correlates of and relationships among specific compensation satisfaction constructs has emerged. Our meta-analysis summarizes this literature.

This meta-analysis serves several purposes. First, many authors have examined relationships among various dimensions of compensation satisfaction, and these relationships have varied greatly from sample to sample. Meta-analysis is the appropriate tool to look across individual samples (that are usually distorted by sampling error) to estimate the relationships among compensation satisfaction dimensions in the population. A second benefit of meta-analysis is that we can assess the likelihood that the relationships between the dimensions of compensation satisfaction are moderated by other constructs. Previous authors have suggested that these relationships are moderated by certain factors (Scarpello, Huber, \& Vandenberg, 1988), so this information will be useful to guide future research.

The third purpose of our meta-analysis is to examine the correlates of compensation satisfaction dimensions. Human resource professionals recognize, and researchers have determined, that compensation satisfaction is a multidimensional construct. Therefore, separate models and theories concerning the antecedents and consequences of the different compensation satisfaction dimensions will be needed to guide future research and practice (Heneman \& Judge, 2000; Heneman, Greenberger \& Fox, 2002; Miceli \& Lane, 1991). Lawler (1971) contributed to this line of research by developing a comprehensive theoretical model of the antecedents of pay level satisfaction. Miceli and Lane (1991) furthered the literature by developing comprehensive antecedent models of several other dimensions of compensation satisfaction; but, rather than testing these models in a comprehensive fashion, empirical studies have tended to examine one or a few antecedents at a time (see Williams, Malos, \& Palmer, 2002 for an exception). Thus, research in these areas has developed in a piecemeal fashion. By summarizing what we know so far about relationships between compensation satisfaction dimensions and 
their antecedents and consequences, this meta-analysis will provide an important step in the development and testing of these individualized theoretical models that are needed to guide future research. The nature of meta-analysis is to analyze past research; therefore, we must rely on compensation correlates that are available in the extant literature for input to our analyses. This paper provides a link between these correlates and compensation satisfaction theory.

\section{RELATIONSHIPS AMONG COMPENSATION SATISFACTION DIMENSIONS}

The majority of studies in this literature utilize the dimensions of compensation satisfaction defined by Heneman and Schwab (1985): satisfaction with pay level, pay raises, benefit level, and pay structure and administration. Pay level refers to the individual's current direct (wage or salary) compensation. Raises refer to the individual's change in pay level. Benefits reflect indirect pay to the individual in the form of payment for time not worked, insurance, etc., and pay structure and administration refers to the hierarchical relationships created among pay rates for different jobs within the organization and procedures by which the pay system is administered (Heneman \& Schwab, 1985). Judge (1993) provided a representative conclusion regarding research on the dimensions of pay satisfaction: "it is clear that the dimensions of pay satisfaction are not independent, and in fact several are highly related" (p. 332), and Heneman and Judge (2000) speculated that relationships among the dimensions are due to the fact that the compensation components themselves are administratively related to one another. For example, pay raises become part of an employee's base pay, so it seems natural that pay raise satisfaction and pay level satisfaction would be related. Thus,

Hypothesis 1: The dimensions of compensation satisfaction will be positively related to each other.

Although Heneman and Judge (2000) argued that components of the compensation system are administratively related to one another, the degree of relationship varies across pairs of dimensions. One could argue that the components related to direct pay are more closely related to one another than any of those components are to satisfaction with benefits. Thus, we expect that levels of satisfaction with dimensions related to direct pay will be more strongly related to each other than they will be to benefit level satisfaction. 
Hypothesis 2: Relationships among pay level, pay raise, and pay structure and administration satisfaction will be stronger than the relationships between each of these three dimensions and benefit level satisfaction.

\section{CORRELATES OF COMPENSATION SATISFACTION}

\section{Antecedents}

Because interest in the antecedents of pay level satisfaction developed so much earlier (i.e., Lawler, 1971) than recognition of and interest in other dimensions of compensation satisfaction, the literature on pay level satisfaction is much larger than the literature related to the other dimensions. Williams, McDaniel, and Nguyen (2006) conducted a metaanalysis of the large body of literature that examined the antecedents of pay level satisfaction; thus, we do not duplicate their results here. Instead we focus on the antecedents of pay raise, benefit, and structure and administration satisfaction.

Pay Raise Satisfaction. Wage or salary, that is the actual amount of pay received, is an important antecedent of pay level satisfaction. Transferring this logic to pay raise satisfaction, a primary determinant of pay raise satisfaction should be the amount of raise received.

Hypothesis 3: Amount of raise will be positively related to pay raise satisfaction.

Also, because many organizations endorse the notion that pay should be based on employee performance (and practice follows this norm, at least to some extent), we expect employee performance level to act as an antecedent of pay raise satisfaction.

Hypothesis 4: Employee performance will be positively related to pay raise satisfaction.

We also expect perceptions of the pay-for-performance contingency within the organization to act as an antecedent of pay raise satisfaction. Employees who perceive that performance is instrumental to the attainment of a valued outcome such as a pay raise, should be more satisfied with their pay raise than those who do not perceive a connection between their performance and valued outcomes (Heneman, Greenberger, \& Strasser, 1988). An additional explanation for a positive 
relationship between pay-for-performance contingency and pay raise satisfaction is that those who are satisfied with their pay raises are likely to believe that their raise was based upon their level of performance or "merit."

Hypothesis 5: Perceived pay-for-performance contingency will be positively related to pay raise satisfaction.

Finally, Shaw, Duffy, Jenkins, and Gupta (1999) noted that dispositional factors considered as antecedents of compensation satisfaction are "conspicuous by their absence" (p. 191); however, we are able to examine the relationship between negative affectivity and pay raise satisfaction. Negative affectivity is a dispositional trait similar to trait anxiety that may predispose individuals to develop negative perceptions (Shaw et al., 1999). Therefore,

Hypothesis 6: Negative affectivity will be negatively related to pay raise satisfaction.

Pay Structure and Administration Satisfaction. We examine one theoretically-derived antecedent of pay structure and administration satisfaction: perceptions of pay-for-performance contingency. Miceli and Lane (1991) argued that perceptions of the way the system "should" operate are important determinants of pay system satisfaction. As noted by Heneman, et al. (1988), many employees in North America are likely to prefer a system in which valued rewards are based upon individual achievement such as job performance. More recent research suggests that the preference for performance contingent rewards may be universal across cultures (Hagan \& Peterson, 1999). Thus,

Hypothesis 7: Perceived pay-for-performance contingency will be positively related to pay structure and administration satisfaction.

Benefit Level Satisfaction. Miceli and Lane (1991) extended Lawler's (1971) work on pay level satisfaction by developing a theoretical model of the antecedents of benefit level satisfaction. Despite this strong theoretical foundation, less empirical research has examined the antecedents of benefit satisfaction. We are able to examine one theoretical antecedent of benefit satisfaction. Miceli and Lane (1991) suggested that employee costs for benefits would be negatively related to benefit level satisfaction. Alternatively, Dreher, Ash, and Bretz (1988) hypothesized that benefit costs would be positively related to benefit satisfaction, because benefit 
costs are likely to be associated with higher quality benefit coverage (a "you-get-what-you-pay-for" line of thinking). Dreher et al.'s (1988) argument must be based on the existence of a positive relationship between the cost of benefits to employees and the level and quality of their benefit coverage. This relationship is unlikely to hold across compensation plans because transferring costs to employees is a method of reducing employer contributions to benefits, not necessarily improving the overall level of benefit coverage. Therefore, we would expect a negative relationship between employee cost for benefits and benefit level satisfaction. A second argument that supports a negative relationship between benefit costs and employee satisfaction with benefits is the notion that employees get used to benefit coverages that come to be viewed as entitlements over time.

Hypothesis 8: Employee cost for benefits will be negatively related to benefit level satisfaction.

\section{Correlates}

The study of compensation satisfaction began as one facet of a broader approach to understanding job satisfaction in general (Smith et al., 1969; Weiss et al., 1967), and the inclusion of compensation satisfaction as an important assessment of employees' satisfaction with their work situations has continued. This body of work allows us to examine the relationships between six other facets of job satisfaction (satisfaction with the work itself, supervisor, coworkers, promotion, organization, and security) and pay level, pay raise, and benefit satisfaction dimensions. We include pay level satisfaction in this section of our meta-analysis because Williams et al. (2006) did not include these other satisfaction correlates in their meta-analysis. We expect all three of these dimensions of compensation satisfaction to be related to all other facets of job satisfaction; however, we also expect dimensions of compensation satisfaction to demonstrate discriminant validity with respect to these other satisfaction facets as explained below. First, a higher salary level provides a greater sense of security to employees, so

Hypothesis 9: Pay level satisfaction will be more strongly related to security satisfaction than to other facets of job satisfaction.

Second, because large pay raises are often associated with job promotions, we expect pay raise satisfaction to more strongly related to promotion satisfaction than any other facet of satisfaction. 
Hypothesis 10: Pay raise satisfaction will be more strongly related to promotion satisfaction than other facets of job satisfaction.

Third, because employee benefits are commonly viewed as an inducement provided by the organization to maintain employee membership, and, because benefits are administered by a distant, perhaps impersonal, human resources department rather than an individual with whom an employee has an ongoing relationship (e.g., a supervisor), we expect benefit level satisfaction to be most strongly related to satisfaction with the company.

Hypothesis 11: Benefit level satisfaction will be more strongly related to satisfaction with the company than to other facets of satisfaction.

\section{Consequences}

Two consequences of the compensation satisfaction dimensions are included in this study: organizational commitment and turnover intentions. Because compensation systems are designed to attract, retain, and motivate employees (as well as to contain costs), we expect a positive relationship between all four compensation satisfaction constructs and organizational commitment. Pay raise, pay structure and administration, and benefit level satisfaction will be negatively related to turnover intentions. (The relationship between pay level satisfaction and turnover intentions is included in Williams et al., 2006.) Thus,

Hypothesis 12: The compensation satisfaction dimensions will be positively related to organizational commitment.

Hypothesis 13: The pay raise, pay structure and administration, and benefit level satisfaction dimensions will be negatively related to turnover intentions.

\section{Other Correlates}

In addition to the relationships described above, we examine demographic correlates (sometimes referred to as personal inputs based on an equity theory approach to pay satisfaction [Heneman, 1985; Miceli \& Lane, 1991]) of three dimensions of compensation satisfaction (the results for pay level satisfaction are included in Williams et al. [2006]). We include these correlates because although early research focused on these factors as drivers of pay level satisfaction (Schwab \& Wallace, 1974), later research (e.g., Dreher, 1981; Heneman, 1985) has indicated 
that these factors do not account for much of the variance in pay level satisfaction. We expect the same to be true of the relationships between demographics and the other three dimensions of compensation satisfaction. Nevertheless, the results in this area will either help to steer future research away from examining these factors, or will point to interesting relationships that deserve further attention. We will also examine the relationship between actual wage or salary and these three dimensions of compensation satisfaction.

\section{METHOD}

\section{Search for Primary Data}

We began with an automated search of PsychInfo (Psychological Abstracts) and $A B I /$ Inform using the key words compensation satisfaction, pay satisfaction, compensation equity, pay equity, compensation fairness and pay fairness. We also manually searched 11 journals from 1960 forward: Academy of Management Journal, Human Relations, Industrial and Labor Relations Review, Industrial Relations, Journal of Applied Psychology, Journal of Management, Journal of Organizational Behavior, Journal of Occupational and Organizational Psychology, Journal of Vocational Behavior, Organizational Behavior and Human Decision Processes, and Personnel Psychology. In addition, we examined empirical studies that included compensation satisfaction dimensions for references to other papers that may have included measures of these dimensions. We requested conference papers and other unpublished works from the authors. These processes identified over 1,400 conceptual and empirical papers, technical reports, conference and working papers, dissertations, books and book chapters related to pay compensation. The majority of these studies included only pay level satisfaction.

\section{Decision Rules}

We included studies in the meta-analyses based on several criteria. First, a study was included only if it contained quantitative data that could be used to calculate an effect size. Several well-known studies of compensation satisfaction were excluded based on this criterion. These studies failed to include correlations among the measures (e.g., Heneman \& Schwab, 1985; Mulvey, Miceli, \& Near, 1992; Orpen \& Bonnici, 1987). Second, only studies that included data based on adults employed full- or part-time or experimental subjects who were actually paid for their work were included. Third, we wanted each sample to be 
represented in each separate meta-analysis only once. For this reason, when we identified multiple studies using the same samples or subsamples, we used correlates from only one study. When there were differences between the data sets (e.g., different sample sizes, a more complete description of the sample), we used data from the study that presented more information. Fourth, we excluded lagged correlations correlations that were calculated based on data collected at two different points in time. Lagged correlations are likely to differ from correlations based on data obtained at the same point in time due to unknown factors that may influence the constructs over the time interval. Because there was an insufficient number of lagged correlation to enable us to examine this factor as a potential moderator, we excluded the samples that reported lagged correlations. Fifth, given our concern with construct validity, we excluded all studies for which we were unable to determine the actual items used to measure either compensation satisfaction or one of its correlates. Sixth, we excluded the few samples that presented data at the group level of analysis. Seventh, some studies did not present a correlation matrix, but chose to report selected correlations within the text. In these cases, we excluded studies in which the authors reported only significant correlations (Rothstein \& McDaniel, 1989).

Following these procedures, we identified 213 samples from 182 studies for inclusion in the meta-analysis. These studies are marked with an asterisk in the reference section.

\section{Coding}

We coded the studies for effect sizes between each pair of compensation satisfaction dimensions and for correlates of the four compensation satisfaction dimensions. Nearly 80 different correlates of these compensation satisfaction dimensions were identified; however, we chose to meta-analyze only those correlates for which we found at least three separate samples $(k>2)$.

\section{Analyses}

We used Hunter and Schmidt's (1990) psychometric meta-analytic procedure and individually corrected coefficients for measurement error. Our analyses provided information on observed and population distributions. We determined the mean and standard deviation of the observed distribution of correlations. After individually correcting each coefficient for measurement error in both variables, we corrected the distribution for sampling error yielding an estimated population distribution. For the population distribution, we estimated its mean, standard deviation and 
the $80 \%$ credibility interval. The computer program that we used is described in McDaniel (1986) and McDaniel, Schmidt, and Hunter (1988, Appendix B).

\section{Interpolation of Reliabilities}

In order to correct for measurement error, it was necessary to obtain a reliability estimate for each measure from each sample. When reliability coefficients were not provided in the primary research report, we interpolated the reliabilities of the compensation satisfaction dimensions and their correlates. First, as expected, different measures of the same compensation satisfaction dimension are represented in this literature. We interpolated reliability coefficients separately for the Pay Satisfaction Questionnaire (PSQ; Heneman \& Schwab, 1985) measures and for the ad hoc measures as a group. For the missing compensation satisfaction reliabilities, the interpolated reliability coefficients are the means of the sample size-weighted mean reliability coefficients from studies that reported this information. (These values are available from the first author.) The reliability for a composite compensation satisfaction measure was the sample size-weighted mean reliability coefficients for the all of the measures of each compensation satisfaction dimension plus .05 . This adjustment recognizes that a composite measure is likely to be more reliable than its component measures. We used a reliability estimate of .65 for single item measures.

Some studies provided reliability estimates for some of the compensation satisfaction correlates. For these correlates (e.g., coworker satisfaction, organizational commitment), we interpolated reliability coefficients in the same way we did for compensation satisfaction. (These values are available from the first author). We interpolated the reliability for composites in the same way as for the compensation satisfaction dimensions. For single item measures, we again used a reliability estimate of .65. No reliability estimates were provided for some of the correlates (raise percentage, age, gender, organizational tenure, education, job classification, and wage or salary). We fixed the reliabilities of these correlates to 1.0. We set the reliability of job performance to .52 based on Viswesvaran, Ones, and Schmidt's (1996) meta-analysis of job performance ratings.

Our reliability data imputation and assumed values will cause the reliabilities to have less variability across studies than actually exists. This will make our estimates of the correlation's population variance upwardly biased. It would not be expected to bias the estimate of the population mean. 


\section{RESULTS}

\section{Relationships among Compensation Satisfaction Dimensions}

We examined relationships among four dimensions of compensation satisfaction, yielding a total of six correlations shown in Table 1 . The population correlations ( $\rho$ 's) are all fairly high (supporting Hypothesis 1). Population correlations between dimensions having to do with cash payments are all .70 or greater, and the population correlations between benefit level satisfaction and the other three compensation satisfaction dimensions are all below .50 ( $\rho=.46$ for pay level, .42 for pay raises, and .48 for pay structure and administration). These results provide support for Hypothesis 2. The benefit level satisfaction items are the ones that have loaded most consistently on a single, separable factor in the previous research on the $\mathrm{PSQ}$, and the results of this meta-analysis also support benefit level satisfaction as a separate dimension of compensation satisfaction.

The second purpose of the meta-analysis was to assess the likelihood that the relationships between compensation satisfaction dimensions are moderated by other variables/constructs. The credibility intervals shown in the last column of Table 1 are relatively narrow. These results suggest

Table 1

Meta-analyses of Relationships Among Compensation Satisfaction Dimensions (tests of Hypotheses 1 and 2)

\begin{tabular}{|c|c|c|c|c|c|c|c|}
\hline \multirow[b]{2}{*}{ Distribution } & \multirow[b]{2}{*}{$k$} & \multirow[b]{2}{*}{$N$} & \multicolumn{2}{|c|}{$\begin{array}{l}\text { Observed } \\
\text { Distribu- } \\
\quad \text { tion }\end{array}$} & \multicolumn{3}{|c|}{$\begin{array}{l}\text { Population } \\
\text { Distribution }\end{array}$} \\
\hline & & & $\bar{r}$ & $\sigma_{\mathrm{r}}$ & $\rho$ & $\sigma_{\rho}$ & $\begin{array}{c}80 \% \\
\text { Credibility } \\
\text { Interval }\end{array}$ \\
\hline Pay level and pay raise & 19 & 6,224 & .69 & .08 & .79 & .10 & .67 to .92 \\
\hline $\begin{array}{l}\text { Pay level and structure } \\
\text { and administration }\end{array}$ & 19 & 5,822 & .62 & .07 & .70 & .05 & .63 to .77 \\
\hline Pay level and benefit level & 23 & 9,632 & .39 & .13 & .46 & .16 & .25 to .66 \\
\hline $\begin{array}{l}\text { Raise and structure } \\
\text { and administration }\end{array}$ & 18 & 5,686 & .66 & .08 & .81 & .08 & .71 to .91 \\
\hline Raise and benefit level & 17 & 6,612 & .36 & .13 & .42 & .15 & .23 to .62 \\
\hline $\begin{array}{l}\text { Structure and administration } \\
\text { and benefit level }\end{array}$ & 18 & 9,271 & .42 & .08 & .48 & .07 & .39 to .57 \\
\hline
\end{tabular}

Note. $k$ number of samples, $N=$ total sample size, $\bar{r}=$ observed mean correlation, $\sigma_{\mathrm{r}}=$ observed standard deviation, $\rho=$ estimated population correlation, $\sigma_{\rho}=$ estimated population standard deviation. 
that moderators of these relationships are small or nonexistent. The variance in the population distribution might be due to differences across studies in the variance of the measures, clerical errors in the primary studies, differences in the construct validity across scales, or study design characteristics (Wilson \& Lipsey, 2001; Hunter \& Schmidt, 1990). It is likely that some of the variance is due to underestimates of the reliability variance across studies that resulted from our imputation and assigned values for missing reliability coefficients. The width of the credibility intervals along with the absolute size of the population correlations ( $\rho$ 's) suggest that the probability of finding a subgroup of studies in which the relationship between these dimensions of compensation satisfaction is substantially different is small. Therefore, if moderators of these relationships could be identified, their effect may slightly change the degree of the positive relationship between constructs, but is unlikely to have any effect on the credibility of our conclusions.

\section{Relationships between Compensation Satisfaction Dimensions and their Correlates}

The results of the meta-analyses of compensation satisfaction correlates are shown in Tables $2-5$. Each table follows the same format as Table 1. We will present the results for antecedents, correlates, and consequences in turn, but first we would like to point out a situation related to three of the compensation satisfaction dimensions. As can be seen in Tables $2-5$, some distributions show zero population variance (i.e., $\sigma_{\rho}=0$ ). This is a common occurrence in meta-analyses of a small number of effect sizes and is most likely attributable to second-order sampling error (Hunter \& Schmidt, 1990). These results represent the best estimate of these relationships based on the available literature, but analyses should be repeated as additional data become available.

Antecedents. The results for compensation satisfaction antecedents are shown in Table 2. Raise amount is moderately related to pay raise satisfaction $(\rho=.32)$, thus Hypothesis 3 is supported. We considered job performance to be an antecedent of pay raise satisfaction, and the population correlation between pay raise satisfaction and all measures of job performance was .38, supporting Hypothesis 4. Four of the samples used supervisory ratings of job performance and one used a self-rating of performance. When we excluded the sample that used the self-rating, the relationship between pay raise satisfaction and job performance was stronger $(\rho=.47)$. Hypothesis 5 was also supported: employee perceptions of pay-for-performance contingencies operating within their organization were strongly related to pay raise satisfaction $(\rho=.65)$. Negative affectivity is negatively related to pay raise satisfaction 
Table 2

Meta-analyses of Antecedents of Compensation Satisfaction Dimensions

\begin{tabular}{|c|c|c|c|c|c|c|c|}
\hline \multirow[b]{2}{*}{ Distribution } & \multirow[b]{2}{*}{$k$} & \multirow[b]{2}{*}{$N$} & \multicolumn{2}{|c|}{$\begin{array}{l}\text { Observed } \\
\text { Distribu- } \\
\quad \text { tion }\end{array}$} & \multicolumn{3}{|c|}{$\begin{array}{l}\text { Population } \\
\text { Distribution }\end{array}$} \\
\hline & & & $\bar{r}$ & $\sigma_{\mathrm{r}}$ & $\rho$ & $\sigma_{\rho}$ & $\begin{array}{l}80 \% \\
\text { Credibility } \\
\text { Interval }\end{array}$ \\
\hline H3 Pay raise and raise amount & 4 & 1,613 & .30 & .05 & .32 & .02 & .29 to .35 \\
\hline $\begin{array}{l}\text { H4 Pay raise and all employee } \\
\text { performance measures }\end{array}$ & 5 & 1,291 & .26 & .20 & .38 & .27 & .04 to .72 \\
\hline $\begin{array}{l}\text { Supervisory ratings of employee } \\
\text { performance }\end{array}$ & 4 & 990 & .32 & .18 & .47 & .24 & .16 to .78 \\
\hline $\begin{array}{l}\text { H5 Pay raise and perceptions of } \\
\text { pay-for-performance contingency }\end{array}$ & 5 & 1,914 & .53 & .05 & .65 & .10 & .52 to .78 \\
\hline H6 Pay raise and negative affectivity & 3 & 499 & -.12 & .05 & -.14 & .00 & -.14 to -.14 \\
\hline $\begin{array}{l}\text { H7 Structure and administration and } \\
\text { perceptions of pay-for-performance } \\
\text { contingency }\end{array}$ & 3 & 1,035 & .44 & .01 & .62 & .00 & .62 to .62 \\
\hline H8 Benefit level and benefit costs & 3 & 1,736 & -.17 & .16 & -.18 & .16 & -.38 to .03 \\
\hline
\end{tabular}

Note. $k=$ number of samples, $N=$ total sample size, $\bar{r}=$ observed mean correlation, $\sigma_{\mathrm{r}}=$ observed standard deviation, $\rho=$ estimated population correlation, $\sigma_{\rho}=$ estimated population standard deviation.

( $\rho=-.14$ ). This relationship, supportive of Hypothesis 6, indicates that the higher the level of negative affectivity, the lower the pay raise satisfaction. In support of Hypothesis 7, employee perceptions of the pay-forperformance contingency were strongly related to pay structure and administration satisfaction $(\rho=.62)$. Finally, benefit costs are moderately and negatively related to benefit satisfaction $(\rho=-.18)$, supporting Hypothesis 8.

Correlates. The results for the correlates of the compensation satisfaction dimensions are shown in Table 3 . The first six correlates address pay level satisfaction. Four of these correlates were analyzed with and without two studies with extreme sample sizes (Steffy \& Jones [1990], $n=8,640$, and Ting [1996], $n=35,717$ ). The results indicate that pay level satisfaction is moderately related to all six dimensions of satisfaction studied and is most strongly related to security satisfaction $(\rho=.41)$, providing support for Hypothesis 9. (However, the $\rho$ between pay level satisfaction and company satisfaction is slightly higher than the $\rho$ between pay level satisfaction and security satisfaction when Steffy and Jones [1990] and Ting [1996] are excluded.). The next five relationships shown in Table 3 include pay raise satisfaction. Pay raise satisfaction 
Table 3

Meta-analyses of Correlates of Compensation Satisfaction Dimensions

\begin{tabular}{|c|c|c|c|c|c|c|c|}
\hline \multirow[b]{2}{*}{ Distribution } & \multirow[b]{2}{*}{$k$} & \multirow[b]{2}{*}{$N$} & \multicolumn{2}{|c|}{$\begin{array}{l}\text { Observed } \\
\text { Distribu- } \\
\quad \text { tion }\end{array}$} & \multicolumn{3}{|c|}{$\begin{array}{l}\text { Population } \\
\text { Distribution }\end{array}$} \\
\hline & & & $\bar{r}$ & $\sigma_{\mathrm{r}}$ & $\rho$ & $\sigma_{\rho}$ & $\begin{array}{l}80 \% \\
\text { Credibility } \\
\text { Interval }\end{array}$ \\
\hline Pay level and work satisfaction & 108 & 46,327 & .23 & .12 & .31 & .14 & .13 to .49 \\
\hline $\begin{array}{l}\text { Work satisfaction without } \\
\text { Steffy and Jones (1990) }\end{array}$ & 107 & 37,687 & .26 & .12 & .33 & .14 & .15 to .52 \\
\hline $\begin{array}{l}\text { Pay level and supervisor } \\
\text { satisfaction }\end{array}$ & 113 & 47,286 & .22 & .12 & .28 & .13 & .11 to .45 \\
\hline $\begin{array}{l}\text { Supervisor satisfaction } \\
\text { without Steffy and } \\
\text { Jones (1990) }\end{array}$ & 112 & 38,646 & .23 & .13 & .29 & .15 & .11 to .48 \\
\hline $\begin{array}{l}\text { Pay level and coworker } \\
\text { satisfaction }\end{array}$ & 102 & 79,328 & .15 & .10 & .21 & .11 & .07 to .35 \\
\hline $\begin{array}{l}\text { Coworker satisfaction } \\
\text { without Steffy and } \\
\text { Jones (1990) and } \\
\text { Ting (1996) }\end{array}$ & 100 & 34,971 & .20 & .13 & .26 & .15 & .08 to .45 \\
\hline $\begin{array}{l}\text { Pay level and promotion } \\
\text { satisfaction }\end{array}$ & 104 & 76,614 & .26 & .13 & .36 & .15 & .17 to .55 \\
\hline $\begin{array}{c}\text { Promotion satisfaction } \\
\text { without Steffy and } \\
\text { Jones (1990) and } \\
\text { Ting (1996) }\end{array}$ & 102 & 32,257 & .33 & .15 & .43 & .18 & .20 to .66 \\
\hline $\begin{array}{l}\text { Pay level and company } \\
\text { satisfaction }\end{array}$ & 14 & 5,926 & .29 & .22 & .37 & .26 & .04 to .70 \\
\hline $\begin{array}{l}\text { H9 Pay level and security } \\
\text { satisfaction }\end{array}$ & 11 & 3,414 & .29 & .13 & .41 & .18 & .18 to .64 \\
\hline $\begin{array}{l}\text { Pay raise and work } \\
\text { satisfaction }\end{array}$ & 5 & 672 & .31 & .11 & .37 & .09 & .25 to 49 \\
\hline $\begin{array}{l}\text { Pay raise and supervisor } \\
\text { satisfaction }\end{array}$ & 5 & 672 & .32 & .13 & .36 & .11 & .21 to .50 \\
\hline $\begin{array}{l}\text { Pay raise and coworker } \\
\text { satisfaction }\end{array}$ & 5 & 672 & .20 & .09 & .23 & .03 & .19 to .27 \\
\hline $\begin{array}{l}\text { H10 Pay raise and promotion } \\
\text { satisfaction }\end{array}$ & 4 & 549 & .52 & .04 & .60 & .00 & .60 to .60 \\
\hline $\begin{array}{l}\text { Pay raise and security } \\
\text { satisfaction }\end{array}$ & 4 & 549 & .10 & .13 & .11 & .12 & -.04 to .26 \\
\hline $\begin{array}{l}\text { Benefit level and work } \\
\text { satisfaction }\end{array}$ & 4 & 7,165 & .21 & .04 & .26 & .04 & .22 to .31 \\
\hline $\begin{array}{l}\text { Benefit level and supervisor } \\
\text { satisfaction }\end{array}$ & 6 & 7,597 & .19 & .09 & .24 & .13 & .08 to .41 \\
\hline $\begin{array}{l}\text { Benefit level and coworker } \\
\text { satisfaction }\end{array}$ & 4 & 7,165 & .22 & .06 & .27 & .03 & .23 to .32 \\
\hline
\end{tabular}


Table 3

Continued

\begin{tabular}{|c|c|c|c|c|c|c|c|}
\hline \multirow[b]{2}{*}{ Distribution } & \multirow[b]{2}{*}{$k$} & \multirow[b]{2}{*}{$N$} & \multicolumn{2}{|c|}{$\begin{array}{l}\text { Observed } \\
\text { Distribu- } \\
\text { tion }\end{array}$} & \multicolumn{3}{|c|}{$\begin{array}{l}\text { Population } \\
\text { Distribution }\end{array}$} \\
\hline & & & $\bar{r}$ & $\sigma_{\mathrm{r}}$ & $\rho$ & $\sigma_{\rho}$ & $\begin{array}{c}80 \% \\
\text { Credibility } \\
\text { Interval }\end{array}$ \\
\hline $\begin{array}{l}\text { Benefit level and promotion } \\
\text { satisfaction }\end{array}$ & 5 & 7,295 & .33 & .04 & .41 & .07 & .32 to .50 \\
\hline $\begin{array}{l}\text { H11 Benefit level and } \\
\text { company satisfaction }\end{array}$ & 3 & 4,281 & .35 & .09 & .43 & .11 & .29 to .56 \\
\hline
\end{tabular}

Note. $k=$ number of samples, $N=$ total sample size, $\bar{r}=$ observed mean correlation, $\sigma_{\mathrm{r}}=$ observed standard deviation, $\rho=$ estimated population correlation, $\sigma_{\rho}=$ estimated population standard deviation.

was at least moderately related to all facets of satisfaction, except security satisfaction. Hypothesis 10 was supported, because pay raise satisfaction was most strongly related to promotion satisfaction $(\rho=.60)$. We examined relationships between benefit level satisfaction and five other facets of satisfaction. The population correlations between these facets and benefit level satisfaction ranged from .24 for supervisor satisfaction to .43 for company satisfaction. As expected, benefit level satisfaction was most strongly related to company satisfaction, supporting Hypothesis 11.

Consequences. Hypothesis 12 states that the compensation satisfaction dimensions will be positively related to organizational commitment. The population correlations shown in Table 4 that range from .34 to .57 support this hypothesis. Data were available to examine the relationship between turnover intentions and only one dimension of compensation satisfaction. The population correlation between turnover intentions and benefit level satisfaction was -.28, providing partial support for Hypothesis 13.

Other Correlates. The results shown in Table 5 indicate that the relationships between demographic variables (i.e., personal and job inputs) and the three compensation satisfaction dimensions of pay raises, pay structure and administration, and benefits are similar to the results obtained for pay level satisfaction (Williams et al., 2006). Across all three compensation satisfaction dimensions, only four population correlations exceeded $\mid .05 \mathrm{I}$. The population correlations between age and pay raise satisfaction and between education and structure and administration 
Table 4

Meta-analyses of Consequences of Compensation Satisfaction Dimensions

\begin{tabular}{|c|c|c|c|c|c|c|c|}
\hline \multirow[b]{2}{*}{ Distribution } & \multirow[b]{2}{*}{$k$} & \multirow[b]{2}{*}{$N$} & \multicolumn{2}{|c|}{$\begin{array}{l}\text { Observed } \\
\text { Distribu- } \\
\quad \text { tion }\end{array}$} & \multicolumn{3}{|c|}{$\begin{array}{l}\text { Population } \\
\text { Distribution }\end{array}$} \\
\hline & & & $\bar{r}$ & $\sigma_{\mathrm{r}}$ & $\rho$ & $\sigma_{\rho}$ & $\begin{array}{l}80 \% \\
\text { Credibility } \\
\text { Interval }\end{array}$ \\
\hline $\begin{array}{l}\text { H12 Pay level and organizational } \\
\text { commitment }\end{array}$ & 49 & 49,308 & .27 & .08 & .34 & .10 & .22 to .47 \\
\hline $\begin{array}{l}\text { Organizational commitment } \\
\text { without Ting (1996) }\end{array}$ & 48 & 13,591 & .23 & .15 & .28 & .17 & .05 to .50 \\
\hline $\begin{array}{l}\text { H12 Pay raise and } \\
\text { organizational commitment }\end{array}$ & 4 & 2,274 & .34 & .05 & .39 & .04 & .34 to .45 \\
\hline $\begin{array}{l}\text { H12 Structure and } \\
\text { administration and } \\
\text { organizational commitment }\end{array}$ & 3 & 1,993 & .49 & .07 & .57 & .05 & .50 to .63 \\
\hline $\begin{array}{l}\text { H12 Benefit level and } \\
\text { organizational commitment }\end{array}$ & 5 & 2,420 & .30 & .07 & .34 & .05 & .27 to .41 \\
\hline $\begin{array}{l}\text { H13 Benefit level and } \\
\text { turnover intentions }\end{array}$ & 4 & 1,157 & -.24 & .05 & -.28 & .00 & -.28 to -.28 \\
\hline
\end{tabular}

Note. $k=$ number of samples, $N=$ total sample size, $\bar{r}=$ observed mean correlation, $\sigma_{\mathrm{r}}=$ observed standard deviation, $\rho=$ estimated population correlation, $\sigma_{\rho}=$ estimated population standard deviation.

satisfaction are the largest $(\rho=-.12)$. In addition, age is negatively related to structure and administration satisfaction $(\rho=-.11)$. Salary grade and pay raise satisfaction are weakly related $(\rho=-.06)$.

Actual wage or salary level is unrelated to pay raise satisfaction $(\rho=.00)$. Actual amount of wage or salary is also unrelated to benefit level satisfaction. Wage or salary is also only slightly related to structure and administration satisfaction. All three of these credibility intervals are wide indicating that moderators of these relationships may exist.

\section{DISCUSSION}

\section{Relationships among Compensation Satisfaction Dimensions}

The results of our meta-analysis provide an estimate of the population correlations obtained across studies using a variety of compensation satisfaction measures and correcting for unreliability in the measures. The results indicate that the relationships between pay level, pay raise, and pay structure and administration satisfaction are substantial 
Table 5

\section{Meta-analyses of Other Correlates of Compensation Satisfaction Dimensions}

\begin{tabular}{|c|c|c|c|c|c|c|c|}
\hline \multirow[b]{2}{*}{ Distribution } & \multirow[b]{2}{*}{$k$} & \multirow[b]{2}{*}{$N$} & \multicolumn{2}{|c|}{$\begin{array}{l}\text { Observed } \\
\text { Distribu- } \\
\quad \text { tion }\end{array}$} & \multicolumn{3}{|c|}{$\begin{array}{l}\text { Population } \\
\text { Distribution }\end{array}$} \\
\hline & & & $\bar{r}$ & $\mathrm{SD}_{\mathrm{r}}$ & $\rho$ & $\sigma_{\rho}$ & $\begin{array}{c}80 \% \\
\text { Credibility } \\
\text { Interval }\end{array}$ \\
\hline Age and pay raise satisfaction & 7 & 3,672 & -.11 & .11 & -.12 & .12 & -.28 to .03 \\
\hline $\begin{array}{l}\text { Age and structure and } \\
\text { administration satisfaction }\end{array}$ & 6 & 3,764 & -.10 & .11 & -.11 & .11 & -.25 to .03 \\
\hline Age and benefit level satisfaction & 10 & 6,494 & .01 & .10 & .01 & .10 & -.12 to .14 \\
\hline Gender and pay raise satisfaction & 5 & 3,351 & .02 & .03 & .03 & .00 & .03 to .03 \\
\hline $\begin{array}{l}\text { Gender and structure and } \\
\text { administration satisfaction }\end{array}$ & 6 & 3,394 & .01 & .09 & .02 & .09 & -.10 to .13 \\
\hline Gender and benefit level satisfaction & 8 & 4,659 & .02 & .11 & .02 & .11 & -.12 to .16 \\
\hline $\begin{array}{l}\text { Organizational tenure and } \\
\text { pay raise satisfaction }\end{array}$ & 9 & 4,399 & .01 & .14 & .00 & .15 & -.19 to .20 \\
\hline $\begin{array}{l}\text { Organizational tenure and structure } \\
\text { and administration satisfaction }\end{array}$ & 5 & 1,135 & -.04 & .06 & -.04 & .00 & -.04 to -.04 \\
\hline $\begin{array}{l}\text { Organizational tenure } \\
\text { and benefit level satisfaction }\end{array}$ & 5 & 1,962 & .03 & .09 & .03 & .08 & -.07 to .13 \\
\hline $\begin{array}{l}\text { Education and structure } \\
\text { and administration satisfaction }\end{array}$ & 3 & 2,674 & -.11 & .03 & -.12 & .00 & -.12 to -.12 \\
\hline Education and benefit level satisfaction & 5 & 4,018 & -.01 & .04 & .00 & .03 & -.04 to .03 \\
\hline Salary grade and pay raise satisfaction & 6 & 4,656 & -.05 & .14 & -.06 & .15 & -.26 to .13 \\
\hline Job tenure and benefit level satisfaction & 3 & 1,734 & -.01 & .11 & -.01 & .10 & -.14 to .12 \\
\hline $\begin{array}{l}\text { Job classification and benefit } \\
\text { level satisfaction }\end{array}$ & 3 & 1,662 & .00 & .05 & .00 & .04 & -.04 to .05 \\
\hline Wage or salary and pay raise satisfaction & 8 & 4,134 & .02 & .15 & .00 & .16 & -.20 to .21 \\
\hline $\begin{array}{l}\text { Wage or salary and structure } \\
\text { and administration satisfaction }\end{array}$ & 10 & 4,248 & -.04 & .13 & -.04 & .14 & -.21 to .14 \\
\hline $\begin{array}{l}\text { Wage or salary and benefit } \\
\text { level satisfaction }\end{array}$ & 13 & 6,107 & .02 & .17 & .02 & .17 & -.20 to .23 \\
\hline
\end{tabular}

Note. $k=$ number of samples, $N=$ total sample size, $\bar{r}=$ observed mean correlation, $\mathrm{SD}_{\mathrm{r}}=$ observed standard deviation, $\rho=$ estimated population correlation, $\sigma_{\rho}=$ estimated population standard deviation. The reliabilities of age, gender, organizational tenure, education, salary grade, job tenure, job classification, and wage or salary were assumed to be 1.0 .

(the average population correlation among these three dimensions is .77). Correlations between these three dimensions are higher than correlations between different measures of a single dimension of compensation satisfaction - pay level. We found three studies that reported correlations between different measures of pay level satisfaction. The correlations in the three studies range from .47 between the JDI and the PSQ (Blau, 
1994) to .71 between an ad hoc measure and the JDI (Shapiro, 1976). Two studies whose sample sizes totaled 968 reported correlations between the MSQ and the PSQ of .52 (Blau, 1994; Scarpello et al., 1988). Thus, available evidence suggests that three of the four dimensions of compensation satisfaction lack discriminant validity. The correlations between benefit level satisfaction and the remaining three dimensions demonstrate discriminant validity: the relationships are more modest (average population correlation of .45) and consistent with a view that these measures represent different constructs.

Although no firm guidelines have been established, population correlations that are near or above .80 call into question both the practical and theoretical utility of continuing to treat these dimensions as separate constructs. The meta-analysis results lend support to authors such as Scarpello et al. (1988) who questioned whether or not it is meaningful to continue to investigate four distinct dimensions of compensation satisfaction. This seems to be particularly true for pay raise satisfaction: the population correlations between pay raise satisfaction and pay level and pay structure/administration satisfaction respectively are .79 and .81. At a minimum, these strong relationships need to be taken into account in future empirical research. Miceli and Lane (1991) developed separate antecedent models for each dimension of compensation satisfaction and Heneman and Judge (2000) suggested that the same approach be taken for theoretical models of the consequences of compensation satisfaction dimensions. To the extent that antecedents or consequences in these models are related to one of the other four compensation satisfaction dimensions and measures of the other dimensions are not included in the studies, the empirical models used to test these relationships will be misspecified and their findings will be suspect.

The meta-analysis results also indicate that the relationships among compensation satisfaction dimensions are reflective of a single underlying population and are not likely to be affected by moderators or characteristics found in individual studies. The credibility intervals are relatively narrow indicating little variability across the studies. The samples represent employees from a variety of job classifications across a wide range of industries. Men and women of different ages, ethnic groups, tenure, and educational backgrounds are included in these studies. Therefore, we believe that a search for moderators of the relationships reported here is not warranted.

\section{Relationships Between Pay Dimensions and their Correlates}

Antecedents. Our results indicate that, beyond pay level satisfaction, researchers have made the most progress toward understanding the antecedents of pay raise satisfaction. We examined three antecedents of 
pay raise satisfaction: raise amount, employee performance, and perceptions of pay-for-performance contingency. The relationship between pay raise amount and pay raise satisfaction $(\rho=.32)$ is similar to the relationship obtained between pay level (or salary) and pay level satisfaction $(\rho=.29$, Williams et al., 2006). In both cases, it is clear that employees respond to factors other than objective determinants when reporting their levels of satisfaction. Pay raise satisfaction is also strongly related to job performance, and the source of performance rating serves as a moderator of the pay raise satisfaction-job performance relationship. The population correlation was .47 for the four samples that used supervisory ratings of job performance and the sample correlation was .04 for the one sample that used a self-rating of job performance. This is logical, because pay raises are typically based on supervisors' ratings of performance.

Meta-analytic results are in the form of bivariate relationships, but we expect that the three antecedents of pay raise satisfaction identified above are interrelated. For this reason, we constructed a meta-analytic correlation matrix including pay raise satisfaction and its three antecedents and subjected the correlation matrix to multiple regression analysis. We used the mean observed correlations from Table 2 and from supplemental meta-analyses of the relationships among the antecedents. The mean observed correlation between raise amount and pay-for-performance contingency was $.22(k=3, N=983)$, between raise amount and supervisory ratings of performance was $.60(k=2, N=766)$ and between pay-for-performance contingency and supervisory ratings of performance was $.12(k=3, N=1067)$. The regression results indicate that these three antecedents explained $35 \%$ of the variance in pay raise satisfaction. Perceptions of pay-for-performance contingency was the strongest predictor of pay raise satisfaction $(\beta=.49)$, followed by performance $(\beta=.23)$ and raise amount $(\beta=.06)$. Raise satisfaction appears to be enhanced, above and beyond the actual raise amount, by employees' beliefs that their pay raises are based on performance levels and by actual performance levels themselves. This should be reassuring to U. S. employers who are likely to endorse and follow a pay-for-performance philosophy.

Pay raise satisfaction was also negatively related to negative affectivity. Whereas Shaw et al. (1999) found that negative affectivity was unrelated to compensation satisfaction dimensions, our meta-analysis results show that negative affectivity is related to pay raise satisfaction. Although this relationship was modest, future examination of the relationship between dispositional factors and compensation satisfaction is warranted.

For pay structure and administration satisfaction, we found that employees prefer pay systems that they perceive to be based on a 
performance-reward contingency $(\rho=.62)$. With respect to benefit satisfaction, the size of employee contributions toward benefits lowers employees' satisfaction with benefits, but not to a great extent $(\rho=-.18)$. Additional primary research on the antecedents of pay structure and administration satisfaction and benefit satisfaction has been conducted, but is not conducive to meta-analysis due to the inclusion of unique antecedents across studies. These areas are especially in need of substantive research based on a unifying framework. As organizations adopt pay system innovations (e.g., skill-based pay) and benefit costs continue to increase (most notably due to rising increases in employer costs for health insurance), it becomes even more critical for organizations to be able to look to research for practical responses. One way in which compensation researchers can be responsive to these concerns is to incorporate justice concepts into compensation research. Organizational justice has become one of the most studied areas within organizational behavior and human resources, yet there are few empirical studies that have integrated organizational justice with the study of pay and benefit system characteristics (see Miceli \& Mulvey, 2000; Williams et al., 2002 for exceptions). Because both internal and external equity as well as perceptions of distributive and procedural justice are dependent on the design of organizational pay systems, this is an area that deserves additional research attention.

Correlates. We examined the relationships between three dimensions of pay satisfaction and other facets of job satisfaction. It is unclear whether these relationships are due to actual covariation among the job conditions responsible for these affective reactions, common method variance, or underlying dispositions. Despite these alternative explanations for the relationships between the pay satisfaction dimensions and other facets of satisfaction, predicted differential relationships between satisfaction facets and pay satisfaction dimensions emerged. These results support the discriminant validity of compensation satisfaction dimensions with respect to other aspects of job satisfaction. Kinicki, McKee-Ryan, Schriesheim, and Carson (2002) conducted a meta-analysis of the JDI job satisfaction facets that included pay level satisfaction. Our findings related to pay level satisfaction extend beyond theirs because we included pay level satisfaction measures in addition to the JDI and included primary studies from a wider variety of sources. Despite these differences, our results are similar. Across the four population correlations between pay level satisfaction and the other JDI facets, our results differed from Kinicki et al.'s (2002) by .04 or less. 
Consequences. Organizational commitment is related to each of the pay satisfaction dimensions, but is most strongly related to pay structure and administration satisfaction. Pay policies and their use may provide signals to employees regarding the organization's culture and the extent to which employees are valued by the organization. Thus, employees who are satisfied with the operation of the compensation system are also committed to the organization that treats them in a satisfactory way. The relationship between benefit satisfaction and turnover intentions is negative $(\rho=-.28)$, indicating that employees who are more satisfied with their benefits are less likely to think about leaving the organization. Others (Heneman \& Judge, 2000) have recommended continuing examination of consequences of compensation satisfaction, and this would be another fruitful area in which to integrate organizational justice concepts.

Other Findings. The other correlates in our study (i.e., demographics and wage level) yielded few sizeable relationships with the pay satisfaction dimensions. The negative relationships between age and both pay raise satisfaction and structure and administration satisfaction are particularly interesting because they run counter to the positive association generally found between age and job satisfaction (Rhodes, 1983), although there is evidence of a curvilinear relationship as well (Kacmar \& Ferris, 1989). A possible explanation for these findings is that older individuals may expect larger raises and other positive treatment with respect to the pay system because of their years of service with the organization. If the organization does not recognize seniority as a factor in determining pay raises or other pay administration activities, older individuals may be dissatisfied. A possible explanation for the negative relationship between pay structure and administration satisfaction and education $(\rho=-.12)$ is that those with higher levels of education are likely to be in more elevated positions within the organization, and may have higher expectations for how they are treated. These unmet expectations may lower satisfaction levels. Finally, although salary is a significant predictor of pay level satisfaction (Williams et al., 2006), it is only weakly related to any of the pay satisfaction constructs studied here. This additional evidence supports the discriminant validity of the compensation satisfaction dimensions; however, we would recommend that wage or salary continue to be included in empirical studies of these other compensation satisfaction dimensions, because our results indicate that moderators of these relationships exist, particularly for benefit level satisfaction and structure and administration satisfaction. 


\section{Limitations and Future Research Suggestions}

The small number of samples available for analysis hampered our search for moderators. However, Hunter and Schmidt (1990) recommended accepting provisionally meta-analytic findings based on a small number of studies while waiting for more data to accumulate rather than relying on single-sample studies or narrative reviews, which are inferior to meta-analysis. Thus, although our analyses should be repeated (and expanded) as more data accumulate, our findings are the best available estimates of the relations between the variables.

Although pay raise satisfaction is typically viewed as an individuallevel phenomenon, benefit satisfaction and pay structure and administration satisfaction may be viewed as organizational- or unit-level phenomena. Several studies that examine compensation satisfaction at the aggregate level exist (e.g., Griffin, Tesluk, \& Jacobs, 1995; Martin, \& Berthiaume, 1995), but more work is needed before these results can be summarized using meta-analysis. We support Heneman and Judge (2000) in calling for the examination of pay satisfaction at levels other than the individual level, and we particularly endorse theoretical developments in these areas.

Finally, meta-analysis is confined to an analysis of previously existing research. We acknowledge that other dimensions of compensation satisfaction may exist, and future research should not be limited to the compensation satisfaction constructs addressed here. Research on other dimensions has begun to appear (e.g., bonus satisfaction [Sturman \& Short, 2000] and benefit system satisfaction [Williams et al., 2002]), and additional meta-analyses will need to be conducted as research in these and other areas accumulates.

\section{CONCLUSION}

This study summarizes the substantive variables related to each of the compensation satisfaction dimensions. Each of the compensation satisfaction constructs deserves more empirical attention based on theoretical models of antecedents and consequences. The current findings can be used as a baseline to design and test theoretical antecedent models such as those suggested by Miceli and Lane (1991). As suggested by Heneman and Judge (2000), specific theoretical models of the consequences of these pay satisfaction dimensions should also be developed and tested. Only primary studies that are based on sound theoretical models specific to each compensation satisfaction dimension and that take into account the strong relationships between some of the compensation satisfaction dimensions will continue to advance the field. 


\section{REFERENCES}

*Adams, E. F., Laker, D. R., \& Hulin, C. L. (1977). An investigation of the influence of job level and functional specialty on job attitudes and perceptions. Journal of Applied Psychology, 62, 335-343.

*Alderfer, C. P. (1967). Convergent and discriminant validation of satisfaction and desire measures by interviews and questionnaires. Journal of Applied Psychology, 51, 509520.

*Angle, H. L., \& Perry, J. L. (1983). Organizational commitment: Individual and organizational influences. Work and Occupations, 10, 123-146.

*Armstrong, T. B. (1969). Occupational level as an indicator of satisfiers and dissatisfiers: A test of Herzberg theory. Unpublished dissertation, Columbia, New York.

*Armstrong, T. B. (1971). Job content and context factors related to satisfaction for different occupational levels. Journal of Applied Psychology, 55, 57-65.

*Balkin, D. B., \& Griffeth, R. W. (1993). The determinants of employee benefits satisfaction. Journal of Business and Psychology, 7, 323-339.

*Barber, A. E., Dunham, R. B., \& Formisano, R. A. (1992). The impact of flexible benefits on employee satisfaction: A field study. Personnel Psychology, 45, 55-75.

*Barling, J., Wade, B., \& Fullagar, C. (1990). Predicting employee commitment to company and union: Divergent models. Journal of Occupational Psychology, 63, 49-61.

*Barnett, R. C., \& Brennan, R. T. (1995). The relationship between job experiences and psychological distress: A structural equation approach. Journal of Organizational Behavior, 16, 259-276.

*Bateman, T. S., \& Strasser, S. (1983). A cross-lagged regression test of the relationships between job tension and employee satisfaction. Journal of Applied Psychology, 68, 439445.

*Bechtold, S. E., Sims, H. P. Jr., \& Szilagyi, A. D. Jr. (1981). Job scope relationships: A three-wave longitudinal analysis. Journal of Occupational Behavior, 2, 189-202.

*Bedeian, A. G., Ferris, G. R., \& Kacmar, K. M. (1992). Age, tenure, and job satisfaction: A tale of two perspectives. Journal of Vocational Behavior, 40, 33-48.

*Bell, R. C., \& Weaver, J. R. (1987). The dimensionality and scaling of job satisfaction: An internal validation of the Worker Opinion Survey. Journal of Occupational Psychology, $60,147-155$.

*Bigoness, W. J. (1978). Correlates of faculty attitudes toward collective bargaining. Journal of Applied Psychology, 63, 228-233.

Blau, G. (1994). Testing the effect of level and importance of pay referents on pay level satisfaction. Human Relations, 47, 1251-1268.

*Blau, G., \& Lunz, M. (1999). Testing the impact of shift schedules on organizational variables. Journal of Organizational Behavior, 20, 933-942.

*Bleda, P. R., Gitter, G. A., \& D’Agostino, R. B. (1977). Enlisted men's perceptions of leader attributes and satisfaction with military life. Journal of Applied Psychology, 62, 43-49.

*Brief, A. P., \& Aldag, R. J. (1980). Antecedents of organizational commitment among hospital nurses. Sociology of Work and Occupations, 7, 210-221.

*Brown, K. A., \& Huber, V. L. (1992). Lowering floors and raising ceilings: A longitudinal assessment of the effects of an earnings-at-risk plan on pay satisfaction. Personnel Psychology, 45, 279-311.

*Bruning, N. S., \& Snyder, R. A. (1983). Sex and position as predictors of organizational commitment. Academy of Management Journal, 26, 485-491.

*Buchko, A. A. (1993). The effects of employee ownership on employee attitudes: An integrated causal model and path analysis. Journal of Management Studies, 30, 633-657.

*Buchko, A. A., Weinzimmer, L. G., \& Sergeyev, A. V. (1997). A comparative analysis of organizational commitment between workers in the United States and Russia. Journal of Managerial Issues, 9, 204-215.

*Carraher, S. M., \& Buckley, M. R. (1996). Cognitive complexity and the perceived dimensionality of pay satisfaction. Journal of Applied Psychology, 81, 102-109.

*Chacko, T. I. (1982). Women and equal employment opportunity: Some unintended effects. Journal of Applied Psychology, 67, 119-123. 
*Champoux, J. E. (1992). A multivariate analysis of curvilinear relationships among job scope, work context satisfaction, and affective outcomes. Human Relations, 45, 87-111.

*Chassie, M. B., \& Bhagat, R. S. (1980). Role stress in working women: Differential effect on selected organizational outcomes. Group and Organization Studies, 5, 224-233.

*Cheloha, R. S., \& Farr, J. L. (1980). Absenteeism, job involvement and job satisfacion in an organizational setting. Journal of Applied Psychology, 65, 467-473.

*Christiansen, N., Villanova, P., \& Mikulay, S. N. (1997). Political influence compatibility: Fitting the person to the climate. Journal of Organizational Behavior, 18, 709-730.

*Cohen, A. (1992). Attitudinal militancy and propensity to strike among unionized engineers and x-ray technicians. Human Relations, 45, 1333-1366.

*Colarelli, S. M., Dean, R. A., \& Konstans, C. N. (1987). Comparative effects of personal and situational influences on job outcomes of new professionals. Journal of Applied Psychology, 72, 558-566.

*Cross, D. (1973). The Worker Opinion Survey: A measure of shop-floor satisfaction. Occupational Psychology, 47, 193-208.

*Davy, J. A., \& Shipper, F. (1993). Voter behavior in union certification elections: A longitudinal study. Academy of Management Journal, 36, 187-199.

*Dreher, G. F. (1981). Predicting the salary satisfaction of exempt employees. Personnel Psychology, 34, 579-589.

*Dreher, G. F., \& Ash, R. A. (1990). A comparative study of mentoring among men and women in managerial, professional, and technical positions. Journal of Applied Psychology, 75, 539-546.

*Dreher, G. F., Ash, R. A., \& Bretz, R. D. (1988). Benefit coverage and employee cost: Critical factors in explaining compensation satisfaction. Personnel Psychology, 41, 237254.

*Driscoll, J. W. (1978). Trust and participation in organizational decision making as predictors of satisfaction. Academy of Management Journal, 21, 44-56.

*Dulebohn, J. H., \& Martocchio, J. J. (1998). Employee perceptions of the fairness of work group incentive pay plans. Journal of Management, 24, 469-488.

*Dunham, R. B. (1977). Reactions to job characteristics: Moderating effects of the organization. Academy of Management Journal, 20, 42-65.

*Dunham, R. B., Smith, F. J., \& Blackburn, R. S. (1977). Validation of the index of Organizational reactions with the JDI, the MSQ, and faces scales. Academy of Management Journal, 20, 420-432.

Dyer, L., \& Theriault, R. N. (1976). The determinants of pay satisfaction. Journal of Applied Psychology, 61, 596-604.

*Eberhardt, B. J., \& Moser, S. B. (1995). The nature and consequences of part-time work: A test of hypotheses. Journal of Applied Business Research, 11, 101-108.

*Ellingson, J. E., Gruys, M. L., \& Sackett, P. R. (1998). Factors related to the satisfaction and performance of temporary employees. Journal of Applied Psychology, 83, 913-921.

*Elloy, D. F., Everett, J. E., \& Flynn, W. R. (1991). An examination of the correlates of job involvement. Group and Organization Studies, 16, 160-177.

*Evans, M. G. (1969). Convergent and discriminant validities between the Cornell Job Descriptive Index and a measure of goal attainment. Journal of Applied Psychology, 53, 102-106.

*Evans, M. G. (1972). Relation among weighted and non-weighted measures of job satisfaction. Studies in Personnel Psychology, 4(2), 45-54.

*Feldman, D. C., \& Tompson, H. B. (1993). Expatriation, repatriation, and domestic geographical relocation: An empirical investigation of adjustment to new job assignments. Journal of International Business Studies, 24, 507-529.

*Fisher, C. D. (2000). Mood and emotions while working: Missing pieces of job satisfaction? Journal of Organizational Behavior, 21, 185-202.

*Folger, R., \& Konovsky, M. A. (1989). Effects of procedural and distributive justice on reactions to pay raise decisions. Academy of Management Journal, 32, 115-130.

*Ford, D. L. Jr. (1985). Facets of work support. Journal of Management, 11, 5-20.

*Futrell, C. M. (1979). Measurement of salespeople's job satisfaction: Convergent and discriminant validity of corresponding INDSALES and Job Descriptive Index scales. Journal of Marketing Research, 16, 594-597. 
*Futrell, C., Parasuraman, A., \& Sagar, J. (1983). Sales force evaluation with expectancy theory. International Marketing Management, 12, 125-129.

*Gannon, M. J., \& Hendrickson, D. H. (1973). Career orientation and job satisfaction among working wives. Journal of Applied Psychology, 57, 339-340.

*Garrison, K. R., \& Muchinsky, P. M. (1977). Attitudinal and biographical predictors of incidental absenteeism. Journal of Vocational Behavior, 10, 221-230.

*Gillet, B., \& Schwab, D. P. (1975). Convergent and discriminant validities of corresponding job descriptive index and Minnesota satisfaction questionnaire scales. Journal of Applied Psychology, 60, 313-317.

*Gomez-Mejia, L. R., \& Balkin, D. B. (1984). Faculty satisfaction with pay and other job dimensions under union and nonunion conditions. Academy of Management Journal, 27, 591-602.

*Graham, M. E., \& Welbourne, T. M. (1999). Gainsharing and women's and men's relative pay satisfaction. Journal of Organizational Behavior, 20, 1027-1042.

*Gregson, T. (1987). Factor analysis of a multiple choice format for job satisfaction. Psychological Reports, 61, 747-750.

*Griffeth, R. W. (1985). Moderation of the effects of job enrichment by participation: A longitudinal field experiment. Organizational Behavior and Human Decision Processes, 35, 73-93.

Griffin, M. A., Tesluk, P. E., \& Jacobs, R. R. (1995). Bargaining cycles and work-related attitudes: Evidence for threat-rigidity effects. Academy of Management Journal, 38, 1709-1725.

*Hackman, J. R., \& Lawler, E. E. III (1971). Employee reactions to job characteristics. Journal of Applied Psychology, 55, 259-286.

Hagan, C. M., \& Peterson, M. F. N. (1999). Cultural specifics and universals in employee responses to pay contingencies. Paper presented at the annual meeting of the Academy of Management, Chicago, IL.

*Hagedoorn, M., VanYperen, N. W., Vliert, E.van de, \& Buunk, B. P. (1999). Employees' negative reactions to problematic events: A circumplex structure of five categories of responses, and the role of job satisfaction. Journal of Organizational Behavior, 20, 309_ 321.

*Hanisch, K. A., \& Hulin, C. L. (1990). Job attitudes and organizational withdrawal: An examination of retirement and other voluntary withdrawal behaviors. Journal of Vocational Behavior, 37, 60-78.

*Hemmasi, M., Graf, L. A., \& Lust, J. A. (1992). Correlates of pay and benefit satisfaction: The unique case of public university faculty. Public Personnel Management, 21, 429443.

Heneman, H. G. III. (1985). Pay satisfaction. In M. Rowland \& J. Ferris (Eds.), Research in Personnel and Human Resources Management, 3, 115-140. Greenwich, CT: JAI Press.

Heneman, H. G. III, \& Judge, T. A. (2000). Compensation attitudes: A review and recommendations for future research. In S. L. Rynes \& B. Gerhart (Eds.). Compensation in Organizations: Progress and prospects, San Francisco: Jossey-Bass.

Heneman, H. G. III, \& Schwab, D. P. (1985). Pay satisfaction: Its multidimensional nature and measurement. International Journal of Psychology, 20, 129-141.

Heneman, R. L., Greenberger, D. B., \& Fox, J. A. (2002). Pay increase satisfaction: A reconceptualization of pay raise satisfaction based on changes in work and pay practices. Human Resource Management Review, 12, 63-74.

*Heneman, R. L., Greenberger, D. B., \& Strasser, S. (1988). The relationship between payfor-performance perceptions and pay satisfaction. Personnel Psychology, 41, 745-759.

*Herman, J. B., \& Hulin, C. L. (1973). Managerial satisfactions and organizational roles: An investigation of Porter's need deficiency scales. Journal of Applied Psychology, 57, 118124.

*Hoffman, K. D., \& Ingram, T. N. (1992). Service provider job satisfaction and customeroriented performance. Journal of Services Marketing, 6, 68-78.

*Holdnak, B. J., Harsh, J., \& Bushardt, S. C. (1993). An examination of leadership style and its relevance to shift work in an organizational setting. Health Care Management Review, 18, 21-30. 
*Hollenbeck, J. R., \& Williams, C. R. (1986). Turnover functionality versus turnover frequency: A note on work attitudes and organizational effectiveness. Journal of Applied Psychology, 71, 606-611.

*Hom, P. W. (1979). Effects of job peripherality and personal characteristics on the job satisfaction of part time workers. Academy of Management Journal, 22, 551-565.

*Hom, P. W., Katerberg, R., \& Hulin, C. L. (1979). Comparative examination of three approaches to the prediction of turnover. Journal of Applied Psychology, 64, 280-290.

*Honeycutt, E. D., Siguaw, J. A., \& Hunt, T. G. (1995). Business ethics and job-related construct: A cross-cultural comparison of automotive salespeople. Journal of Business Ethics, 14, 235-248.

*Howard, L. W. (1999). Validity evidence for measures of procedural/distributive justice and pay/benefit satisfaction. Journal of Business and Psychology, 14, 135-147.

*Huber, V. L., Seybolt, P. M., \& Venemon, K. (1992). The relationship between individual inputs, perceptions, and multidimensional pay satisfaction. Journal of Applied Social Psychology, 22, 1356-1373.

*Hunt, J. W., \& Saul, P. N. (1975). The relationship of age, tenure, and job satisfaction in males and females. Academy of Management Journal, 18, 690-702.

Hunter, J. E., \& Schmidt, F. L. (1990). Methods of meta-analysis: Correcting error and bias in research findings. Newbury Park, CA: Sage.

*Igbaria, M., \& Guimaraes, T. (1993). Antecedents and consequences among information center employees. Journal of Management Information Systems, 9, 145-174.

*Jauch, L. R., \& Sekaran, U. (1978). Employee orientation and job satisfaction among professional employees in hospitals. Journal of Management, 4, 43-56.

*Jenkins, G. D. Jr., \& Lawler, E. E. III. (1981). Impact of employee participation in pay plan development. Organizational Behavior and Human Performance, 28, 111-128.

*Jermier, J. M., Gaines, J., \& McIntosh, N. J. (1989). Reactions to physically dangerous work: A conceptual and empirical analysis. Journal of Organizational Behavior, 10, 1533.

*Johnson, S. M., Smith, P. C., \& Tucker, S. M. (1982). Response format of the job descriptive index: Assessment of reliability and validity by the multitrait-multimethod matrix. Journal of Applied Psychology, 67, 500-505.

*Johnston, M. W., Varadarajan, P. R., Futrell, C. M., \& Sager, J. (1987). The relationship between organizational commitment, job satisfaction, and turnover among new sales people. Journal of Personal Selling and Sales Management, 7, 29-38.

*Jones, S., \& Bergmann, T. (1999). Pay procedures - what makes them fair? Journal of Occupational and Organizational Psychology, 72, 129-145.

*Judge, T. A. (1993). Validity of the dimensions of the pay satisfaction questionnaire: Evidence of differential prediction. Personnel Psychology, 46, 331-355.

*Judge, T. A., \& Hulin, C. L. (1993). Job satisfaction as a reflection of disposition: A multiple source causal analysis. Organizational Behavior and Human Decision Processes, 56, $388-421$.

Judge, T. A., \& Welbourne, T. M. (1994). A confirmatory investigation of the dimensionality of the pay satisfaction questionnaire. Journal of Applied Psychology, 79, 461-466.

*Kacmar, K. M., \& Ferris, G. R. (1989). Theoretical and methodological considerations in the age-job satisfaction relationship. Journal of Applied Psychology, 74, 201-207.

*Kantak, D. M., Futrell, C. M., \& Sagar, J. K. (1992). Job satisfaction and life satisfaction in a sales force. Journal of Personal Selling and Sales Management, 12, 1-7.

*Kerber, K. W., \& Campbell, J. P. (1987). Component structure of a measure of job facet satisfaction: Stability across job levels. Educational and Psychological Measurement, $47,825-835$.

Kinicki, A. J., McKee-Ryan, F. M., Schriesheim, C. A., \& Carson, K. P. (2002). Assessing the construct validity of the job descriptive index: A review and meta-analysis. Journal of Applied Psychology, 87, 14-32.

*Koch, J. L., \& Rhodes, S. R. (1981). Predictors of turnover of female factory workers. Journal of Vocational Behavior, 18, 145-161.

*Lam, S. S. K. (1998). A validity study of the pay satisfaction questionnaire in Hong Kong. Journal of Social Psychology, 138, 124-125. 
*Lane, M. C. (1992:1993). The effect of employee benefit satisfaction on organizational consequences. Paper presented at the Industrial Relations Research Association.

*LaVan, H., \& Banner, D. K. (1985). The perception of role conflict, role ambiguity and organisational commitment: Differences between sexes. International Journal of Manpower, 6, 32-35.

Lawler, E. E. III. (1971). Pay and organizational effectiveness. New York: McGraw-Hill.

*Lee, C., Law, K. S., \& Bobko, P. (1999). The importance of justice perceptions on pay effectiveness: A two-year study of a skill-based pay plan. Journal of Management, 25, 851-873.

*Lefkowitz, J., \& Brigando, L. (1980). The redundancy of work alienation and job satisfaction: Some evidence of convergent and discriminant validity. Journal of Vocational Behavior, 16, 115-131.

*Leigh, J. H., \& Futrell, C. M. (1985). From the trenches to the command post: Perceptual and attitudinal differences between levels in the marketing management hierarchy. Journal of Business Research, 13, 511-536.

*Leigh, J. H., Lucas, G. H. Jr., \& Woodman, R. W. (1988). Effects of perceived organizational factors on role stress-job attitude relationships. Journal of Management, 14, 41-58.

*Levanoni, E., \& Sales, C. A. (1989). Differences in job attitudes between full-time and parttime Canadian employees. Journal of Social Psychology, 130, 231-237.

*Logan, N., O’Reilly, C. A. III, \& Roberts, K. H. (1973). Job satisfaction among part-time and full-time employees. Journal of Vocational Behavior, 3, 33-41.

*Lopez, E. M. (1982). A test of the self-consistency theory of the job performance-job satisfaction relationship. Academy of Management Journal, 25, 335-348.

*Lum, L., Kervin, J., Clark, K., Reid, F., \& Sirola, W. (1998). Explaining nursing turnover intent: Job satisfaction, pay satisfaction, or organizational commitment? Journal of Organizational Behavior, 19, 305-320.

*Lust, J. A., \& Werling, S. J. (1990). The impact of alternate information sources on compensation satisfaction. Journal of Business and Psychology, 4, 357-364.

*MacEachron, A. E. (1977). Two interactive perspectives on the relationship between job level and job satisfaction. Organizational Behavior and Human Performance, 19, 226246.

*Maimon, Z., \& Ronen, S. (1978). Measures of job facet satisfaction as predictors of the tendency to leave or the tendency to stay with an organization. Human Relations, 31, 1019-1030.

*Malka, S. (1989). Managerial behavior, participation, and effectiveness in social welfare organizations. Administration in Social Work, 13, 47-65.

*Martelli, T. A., Waters, L. K., \& Martelli, J. (1989). The police stress survey: Reliability and relation to job satisfaction and organizational commitment. Psychological Reports, 64, $267-273$.

Martin, J. E., \& Berthiaume, R. D. (1995). Predicting the outcome of a contract ratification vote. Academy of Management Journal, 38, 916-928.

*Martin, C. L., \& Bennett, N. (1996). The role of justice judgments in explaining the relationship between job satisfaction and organizational commitment. Group and Organization Management, 21, 84.

*Mathieu, J. E., Hofmann, D. A., \& Farr, J. L. (1993). Job perception-job satisfaction relations: An empirical comparison of three competing theories. Organizational Behavior and Human Decision Processes, 56, 370-387.

*McCabe, D. J., Dalessio, A., Briga, J., \& Sasaki, J. (1980). The convergent and discriminant validities between the IOR and the JDI: English and Spanish forms. Academy of Management Journal, 23, 778-786.

McDaniel, M. A. (1986). Computer programs for calculating meta-analysis statistics. Educational and Psychological Measurement, 46, 175-177.

McDaniel, M. A., Schmidt, F. L., \& Hunter, J. E. (1988). A meta-analysis of methods for rating training and experience in personnel selection. Personnel Psychology, 41, 283314.

*McElroy, J. C., Morrow, P. C., Crum, M. R., \& Dooley, F. J. (1995). Railroad employee commitment and work-related attitudes and perceptions. Transportation Journal, 34(3), 13-24. 
*McFarlin, D. B., \& Frone, M. R. (1990). A two-tier wage structure in a non-union firm. Industrial Relations, 29, 145-154.

*McFarlin, D. B., \& Sweeney, P. D. (1992). Distributive and procedural justice as predictors of satisfaction with personal and organizational outcomes. Academy of Management Journal, 35, 626-637.

*McGinnis, S. K., \& Morrow, P. S. (1990). Job attitudes among full and part-time employees. Journal of Vocational Behavior, 36, 86-96.

*McNeilly, K. M., \& Russ, F. A. N. (1992). The moderating effect of sales force performance on relationships involving antecedents of turnover. Journal of Personal Selling \& Sales Management, 12, 9-20.

Miceli, M. P., \& Lane, M. C. (1991). Antecedents of pay satisfaction: A review and extension. In K. Rowland \& J. Ferris (Eds.), Research in Personnel and Human Resources Management, 9, 235-309. Greenwich, CT: JAI Press.

*Miceli, M. P., \& Mulvey, P. W. (2000). Consequences of satisfaction with pay systems: Two field studies. Industrial Relations, 39, 62-87.

*Morgeson, F. P., Campion, M. A., \& Maertz, C. P. (2001). Understanding pay satisfaction: The limits of a compensation system implementation. Journal of Business and Psychology, 16, 133-149.

*Morrow, P. C., \& Crum, M. R. (1998). The effects of perceived and objective safety risk on employee outcomes. Journal of Vocational Behavior, 53, 300-313.

*Morrow, P. C., \& McElroy, J. C. (1987). Work commitment and job satisfaction over three career stages. Journal of Vocational Behavior, 30, 330-346.

*Mottaz, C. (1986). Gender differences in work satisfaction, work-related rewards and values, and the determinants of job satisfaction. Human Relations, 39, 359-378.

*Mowday, R. T., Steers, R. M., \& Porter, L. W. (1979). The measurement of organizational commitment. Journal of Vocational Behavior, 14, 224-247.

*Mueller, C. W., Iverson, R. D., \& Jo, D. -G. (1999). Distributive justice evaluations in two cultural contexts: A comparison of U.S. and South Korean teachers. Human Relations, $52,869-893$.

Mulvey, P. W., Miceli, M. P., \& Near, J. P. (1992). The pay satisfaction questionnaire: A confirmatory factor analysis. Journal of Social Psychology, 132, 139-141.

*Newman, J. E. (1974). Predicting absenteeism and turnover: A field comparison of Fishbein's model and traditional job attitude measures. Journal of Applied Psychology, 59, 610-615.

*Newman, J. E. (1975). Understanding the organizational structure: Job attitude relationship through perceptions of the work environment. Organizational Behavior and Human Performance, 14, 371-397.

*Norris, D. R., \& Niebuhr, R. E. (1983). Professionalism, organizational commitment and job satisfaction in an accounting organization. Accounting, Organizations and Society, $9,49-59$.

*Norris, D. R., \& Niebuhr, R. E. (1984). Attributional influences on the job performance-job satisfaction relationship. Academy of Management Journal, 27, 424-431.

*Oldham, G. R., Hackman, J. R., \& Pearce, J. L. (1976). Conditions under which employees respond positively to enriched work. Journal of Applied Psychology, 61, 395-403.

*Oldham, G. R., Kulik, C. T., Ambrose, M. L., Stepina, L. P., \& Brand, J. F. (1986). Relations between job facet comparisons and employee reactions. Organizational Behavior and Human Decision Processes, 38, 28-47.

*O'Reilly, C. A. III, Bretton, G. E., \& Roberts, K. H. (1974). Professional employees' preferences for upward mobility: An extension. Journal of Vocational Behavior, 5, 139-145.

*O'Reilly, C. A. I., \& Caldwell, D. F. (1985). The impact of normative social influence and cohesiveness on task perceptions and attitudes: A social information processing approach. Journal of Occupational Psychology, 58, 193-206.

*Orpen, C. (1986). Correlates of pay satisfaction. Psychological Reports, 59, 1205-1206.

Orpen, C., \& Bonnici, J. (1987). A factor analytic investigation of the pay satisfaction questionnaire. Journal of Social Psychology, 127, 391-392.

*Ostroff, C., Kinicki, A. J., \& Clark, M. A. (2002). Substantive and operational issues of response bias across levels of analysis: An example of climate-satisfaction relationships. Journal of Applied Psychology, 87, 355-368. 
*Parasuraman, S. (1982). Predicting turnover intentions and turnover behavior: A multivariate analysis. Journal of Vocational Behavior, 21, 111-121.

*Parasuraman, A., \& Futrell, C. M. (1983). Demographics, job satisfaction, and propensity to leave of industrial salesmen. Journal of Business Research, 11, 33-48.

*Penley, L. E., \& Hawkins, B. L. (1980). Organizational communication, performance, and job satisfaction as a function of ethnicity and sex. Journal of Vocational Behavior, 16, 368-384.

*Podsakoff, P. M., Todor, W. D., \& Skov, R. (1982). Effects of leader contingent and noncontingent reward and punishment behaviors on subordinate performance and satisfaction. Academy of Management Journal, 25, 810-821.

*Pond, S. B. III, \& Geyer, P. D. (1991). Differences in the relation between job satisfaction and perceived work alternatives among older and younger blue collar workers. Journal of Vocational Behavior, 39, 251-262.

Rhodes, S. R. (1983). Age-related differences in work attitudes and behavior: A review and conceptual analysis. Psychological Bulletin, 93, 328-367.

*Ronen, S. (1978). Personal values: A basis for work motivational set and work attitude. Organizational Behavior and Human Performance, 21, 80-107.

*Ronen, S. (1986). Equity perception in multiple comparisons: A field study. Human Relations, 39, 333-346.

Rothstein, H. R., \& McDaniel, M. A. (1989). Guidelines for conducting and reporting metaanalyses. Psychological Reports, 65, 759-770.

*Roznowski, M., \& Hanisch, K. A. (1990). Building systematic heterogeneity into work attitudes and behavior measures. Journal of Vocational Behavior, 36, 361-375.

*Roznowski, M., \& Hulin, C. L. (1985). Influences of functional specialty and job technology on employees' perceptual and affective responses to their jobs. Organizational Behavior and Human Decision Processes, 36, 186-208.

*Saal, F. E. (1978). Job involvement: A multivariate approach. Journal of Applied Psychology, 63, 53-61.

*Sarata, B. P. V. (1974). Employee satisfactions in agencies serving retarded persons. American Journal of Mental Deficiency, 79, 434-442.

*Sauser, W. I., \& York, M. (1978). Sex differences in job satisfaction: A reexamination. Personnel Psychology, 31, 537-547.

*Scarpello, V., \& Campbell, J. P. (1983). Job satisfaction: Are all the parts there? Personnel Psychology, 36, 577-600.

*Scarpello, V., Huber, V., \& Vandenberg, R. J. (1988). Compensation satisfaction: Its measurement and dimensionality. Journal of Applied Psychology, 73, 163-171.

*Scarpello, V., \& Vandenberg, R. (1987). The Satisfaction With My Supervisor Scale: Its utility for research and practical applications. Journal of Management, 13, 447-466.

*Schaubroeck, J., Ganster, D. C., \& Kemmerer, B. (1996). Does trait affect promote job attitude stability? Journal of Organizational Behavior, 17, 191-196.

*Schneider, B., \& Snyder, R. A. (1975). Some relationships between job satisfaction and organizational climate. Journal of Applied Psychology, 60, 318-328.

Schwab, D. P., \& Wallace, M. J. (1974). Correlates of employee satisfaction with pay. Industrial Relations, 13, 78-89.

*Seers, A. (1989). Team-member exchange quality: A new construct for role-making research. Organizational Behavior and Human Decision Processes, 43, 118-135.

*Seers, A., \& Graen, G. B. (1984). The dual attachment concept: A longitudinal investigation of the combination of task characteristics and leader-member exchange. Organizational Behavior and Human Performance, 33, 283-306.

Shapiro, H. J. (1976). Models of pay satisfaction: A comparative study. Psychological Reports, 39, 223-230.

*Shapiro, H. J., \& Wahba, M. A. (1978). Pay satisfaction: An empirical test of a discrepancy model. Management Science, 24, 612-622.

*Shaw, J. D., Duffy, M. K., Jenkins, G. D., \& Gupta, N. N. (1999). Positive and negative affect, signal sensitivity, and pay satisfaction. Journal of Management, 25, 189-206.

*Shore, L. M., \& Tetrick, L. E. (1991). A construct validity study of the survey of perceived organizational support. Journal of Applied Psychology, 76, 637-643. 
*Smart, R., \& Peterson, C. N. (1994). Stability versus transition in women's career development: A test of Levinson's theory. Journal of Vocational Behavior, 45, 241-260.

*Smith, P. C., Kendall, L. M., \& Hulin, C. L. (1969). The measurement of satisfaction in work and retirement: A strategy for the study of attitudes. Chicago: Rand McNally.

*Snyder, C. D., \& Ferguson, L. W. (1976). Self-concept and job satisfaction. Psychological Reports, 38, 603-610.

*Snyder, R. A., Verderber, K. S., \& Morris, J. H. (1986). Voluntary union membership of women and men: Differences in personal characteristics, perceptions and attitudes. Journal of Occupational Psychology, 59, 205-216.

*Soutar, G. N., \& Weaver, J. R. (1982). The measurement of shop-floor job satisfaction: The convergent and discriminant validity of the worker opinion survey. Journal of Occupational Psychology, 55, 27-33.

*Spector, P. E. (1985). Measurement of human service staff satisfaction: Development of the job satisfaction survey. American Journal of Community Psychology, 13, 693-713.

*Steffy, B. D., \& Jones, J. W. (1990). Differences between full-time and part-time employees in perceived role strain and work satisfaction. Journal of Organizational Behavior, 11, 321-329.

*Stepina, L. P., Hassell, B. L., Harris, J. R., \& Mayfield, C. R. (1991). A comparative test of the independent effects of interpersonal, task, and reward domains on personal and organizational outcomes. Journal of Social Behavior and Personality, 6, 93-104.

*Stone, E. F. (1975). Job scope, job satisfaction, and the Protestant Ethic: A study of enlisted men in the U.S. Navy. Journal of Vocational Behavior, 7, 215-224.

*Stone, E. F. (1976). The moderating effect of work-related values on the job scope-job satisfaction relationship. Organizational Behavior and Human Performance, 15, 147167.

*Stone, E. F., \& Porter, L. W. (1975). Job characteristics and job attitudes: A multivariate study. Journal of Applied Psychology, 60, 57-64.

*Stroh, L. K., Brett, J. M., \& Reilly, A. H. (1996). Family structure, glass ceiling, and traditional explanation for the differential rate of turnover of female and male managers. Journal of Vocational Behavior, 49, 99-118.

*Stumpf, S. A., \& Rabinowitz, S. (1981). Career stage as a moderator of performance relationships with facets of job satisfaction and role perceptions. Journal of Vocational Behavior, 18, 202-218.

*Sturman, M. C., Hannon, J. M., \& Milkovich, G. T. (1996). Computerized decision aids for flexible benefits decisions: The effects of an expert system and decision support system on employee intentions and satisfaction with benefits. Personnel Psychology, 49, 883908.

*Sturman, M. C., \& Short, J. C. (2000). Lump-sum bonus satisfaction: Testing the construct validity of a new pay satisfaction dimension. Personnel Psychology, 53, 673-700.

*Sweeney, P. D., \& McFarlin, D. B. (1993). Workers' evaluations of the "ends" and the "means": An examination of four models of distributive and procedural justice. Organizational Behavior and Human Decision Processes, 55, 23-40.

*Tang, T. L. P., \& Sarsfield-Baldwin, L. J. (1996). Distributive and procedural justice as related to satisfaction and commitment. S.A.M. S.A.M. Advanced Management Journal, 61(3), 25-31.

*Tiegs, R. B., Tetrick, L. E., \& Fried, Y. (1992). Growth need strength and context satisfactions as moderators of the relations of the Job Characteristics Model. Journal of Management, 18, 575-593.

*Ting, Y. (1996). Analysis of job satisfaction of the federal white-collar work force: Findings from the Survey of Federal Employees. American Review of Public Adminsitration, 26, 439-456.

*Tremblay, M., Roger, A., \& Toulouse, J. M. (1995). Career plateau and work attitudes: An empirical study of managers. Human Relations, 48, 221-237.

*Tremblay, M., Sire, B., \& Balkin, D. (1999). The role of organizational justice in pay and employee benefit satisfaction, and its effects on work attitudes. Paper presented at the Academy of Management, Chicago.

*Tremblay, M., Sire, B., \& Pelchat, A. (1998). A study of the determinants and of the impact of flexibility on employee benefit satisfaction. Human Relations, 51, 667-688. 
*Vest, M. J., Scott, K. D., \& Markham, S. E. (1994). Self-rated performance and pay satisfaction, merit increase satisfaction, and instrumentality beliefs in a merit pay environment. Journal of Business and Psychology, 9, 171-181.

Viswesvaran, C., Ones, D. S., \& Schmidt, F. L. (1996). Comparative analysis of the reliability of job performance ratings. Journal of Applied Psychology, 81, 557-574.

*Wanberg, C. R., Carmichael, H. D., \& Downey, R. G. (1999). Satisfaction at last job and unemployment: A new look. Journal of Organizational Behavior, 20, 121-131.

*Warr, P. B., \& Routledge, T. (1969). An opinion scale for the study of managers' job satisfaction. Occupational Psychology, 43, 95-109.

*Watson, D., \& Slack, A. K. (1993). General factors of affective temperament and their relation to job satisfaction over time. Organizational Behavior and Human Decision Processes, 54, 181-202.

*Weiner, N. (1980). Determinants and behavioral consequences of pay satisfaction: A comparison of two models. Personnel Psychology, 33, 741-757.

Weiss, D. J., Dawis, R. V., England, G. W., \& Lofquist, L. H. (1967). Manual for the Minnesota Satisfaction Questionnaire. Minneapolis: Work Adjustment Project University of Minnesota Industrial Relations Center.

*Welbourne, T. M., \& Cable, D. M. (1995). Group incentives and pay satisfaction: Understanding the relationship through an identity theory perspective. Human Relations, 48 , 711-726.

*Welsch, H. P., \& LaVan, H. (1981). Inter-relationships between organizational commitment and job characteristics, job satisfaction, professional behavior, and organizational climate. Human Relations, 34, 1079-1089.

*Williams, M. L. (1995). Antecedents of employee benefit level satisfaction: A test of a model. Journal of Management, 21, 1097-1128.

Williams, M. L., McDaniel, M. A., \& Nguyen, N. T. (2006). A meta-analysis of the antecedents and consequences of pay level satisfaction. Journal of Applied Psychology, 91, 392-413.

*Williams, M. L., Malos, S. B., \& Palmer, D. K. (2002). Benefit system and benefit level satisfaction: An expanded model of antecedents and consequences. Journal of Management, 28, 195-215.

Wilson, D. B., \& Lipsey, M. W. (2001). The role of method in treatment effectiveness research: Evidence from meta-analysis. Psychological Methods, 6, 413-429.

*Witt, L. A. (1989). Sex differences among bank employees in the relationships of commitment with psychological climate and job satisfaction. Journal of General Psychology, 116, 267-273.

*Witt, L. A. (1992). Exchange ideology as a moderator of the relationships between importance of participation in decision making and job attitudes. Human Relations, 45, 73-85.

*Yeager, S. J. (1981). Dimensionality of the job descriptive index. Academy of Management Journal, 24, 205-212.

*Young, B. S., Worchel, S., \& Woehr, D. J. (1998). Organizational commitment among public service employees. Public Personnel Management, 27, 339-348. 